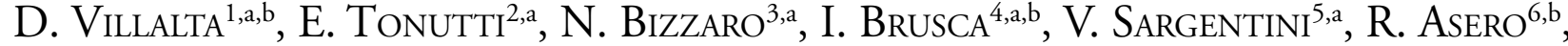

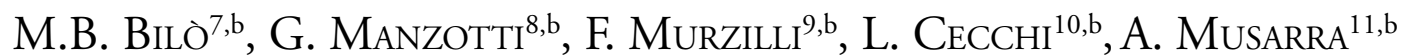

\section{Recommendations for the use of molecular diagnostics in the diagnosis of allergic diseases}

\author{
${ }^{1}$ Allergologia e Immunologia Clinica, Ospedale S. Maria degli Angeli, Pordenone, Italy \\ ${ }^{2}$ Immunopatologia e Allergologia, Azienda Ospedaliero-Universitaria, Udine, Italy \\ ${ }^{3}$ Laboratorio di Patologia Clinica, Ospedali di Tolmezzo, Gemona, San Daniele (UD), Italy \\ ${ }^{4}$ Laboratorio Analisi, Ospedale Buccheri-La Ferla, Palermo, Italy \\ ${ }^{5}$ Laboratorio Analisi, P.T.P, Nuovo Regina Margherita, Roma, Italy \\ ${ }^{6}$ Ambulatorio di Allergologia, Clinica San Carlo, Paderno Dugnano (MI), Italy \\ ${ }^{7}$ UOC di Allergologia, Azienda Ospedaliera-Universitaria Ospedali Riuniti, Ancona, Italy \\ ${ }^{8}$ Ambulatorio di allergologia, Dipartimento Area Medica, Ospedale di Treviglio (BG), Italy \\ ${ }^{9}$ UOSD di Allergologia, Ospedale S.S. Filippo e Nicola, Avezzano (AQ), Italy \\ ${ }^{10}$ SOC Allergologia e Immunologia Clinica, USL Toscana Centro, Prato, Italy \\ ${ }^{11}$ Servizio di Allergologia, Casa della Salute di Scilla, Scilla (RC), Italy
}

${ }^{2}$ Gruppo di Studio in Allergologia della Società Italiana di Patologia Clinica e Medicina di Laboratorio (GdS-ALL SIPMeL)

${ }^{b}$ Associazione Italiana degli Allergologi e Immunologi Territoriali e Ospedalieri (AAIITO)

\section{KEY WORDS}

allergy; molecular diagnostics; component resolved diagnostics; guidelines; specific IgE

\section{Corresponding author \\ Danilo Villalta \\ Ospedale di Pordenone \\ Pordenone, Italy \\ E-mail: danilo.villalta@aas5.sanita.fvg.it}

Doi

10.23822/EurAnnACI.1764-1489.32

\begin{abstract}
Summary
The Study Group on Allergology of the Italian Society of Clinical Pathology and Laboratory Medicine (SIPMeL) and the Associazione Italiana degli Allergologi e Immunologi Territoriali $e$ Ospedalieri (AAIITO) developed the present recommendations on the diagnosis of allergic diseases based on the use of molecular allergenic components, whose purpose is to provide the pathologists and the clinicians with information and algorithms enabling a proper use of this second-level diagnostics. Molecular diagnostics allows definition of the exact sensitization profile of the allergic patient. The methodology followed to develop these recommendations included an initial phase of discussion between all the components to integrate the knowledge derived from scientific evidence, a revision of the recommendations made by Italian and foreign experts, and the subsequent production of this document to be disseminated to all those who deal with allergy diagnostics.
\end{abstract}

\section{Background}

- Many allergens are antigenically extremely complex.

- An extract is a mixture of proteins, only part of whom are allergens.

- Every allergic subject responds to one or more allergen based on his/her genetic background.

- A number of cross-reacting allergens exist, and are variably distributed throughout plants and animals: their structural homology is variable. A minimum $35-40 \%$ amino acid ho- mology is needed to cause cross-reactivity.

- Both conformational and linear epitopes exist.

- There are marked differences in molecular sensitization patterns between different geographical regions.

\section{Usefulness of component resolved diagnosis (CRD)}

Molecules show a well-defined composition, can be quantified precisely, lack non-allergenic components, and can be produced in 
large amounts in-vitro. CRD defines the precise allergy profile of each individual patient (1). In patients showing multi-sensitization using traditional extracts, this leads to discriminate genuine sensitizations from sensitizations caused by cross-reacting molecules (2). In respiratory allergy, this translates into the choice of the correct immunotherapy $(3,4)$; in food allergy in the correct evaluation of the risk of severe allergic reactions based on the physical / chemical characteristics of the relevant allergens (5); in latex allergy in the correct identification of true allergic subjects needing a latex-safe environment (6); and in hymenoptera venom allergy in discriminating between honey bee and wasp allergy and within the wasp family, looking for the right venom immunotherapy (7).

\section{Main classes of molecules}

Molecules list is regularly updated into the Official list of allergens of the International Union of Immunological Societies Allergen Nomenclature sub-committee of the WHO (WHO/IUIS) (http://www.allergen.org). Although molecules may belong to more than 120 protein families, allergens responsible for most allergic reactions belong to few protein families characterized by a limited number of biologic functions (8).

\section{Respiratory allergy}

Table I (p. 54) shows the major and minor specific molecular components along with the main cross-reacting molecules.

\section{Food allergy}

\section{Plant-derived foods}

The main genuine, heat- and pepsin-stable plant-food allergens include: a) Nonspecific Lipid Transfer Proteins (nsLTP). They belong to PR-14, and are typically located near the peel. nsLTP from Rosaceae family are highly homologous; b) $2 \mathrm{~S}$ Albumins (prolamin superfamily) are small storage proteins. They are the major allergen in nuts and seeds. Homology is quite high between cashew and pistachio, sesame and Brassicaceae, and reaches $60 \%$ between walnut and hazelnut; c) Vicilins ( $7 \mathrm{~S}$ globulins) (cupin superfamily) are storage proteins causing allergy to fruits and legumes; d) Legumins (11S globulins) (cupin superfamily) are storage proteins causing allergy to fruits and legumes; e) Gliadins ( $\omega-5$ gliadin) (prolamin superfamily) cause wheat allergy.

Molecules involved in cross-reactivity with pollen allergens are heat- and pepsin-sensitive, are in most cases associated with symptoms limited to the oral cavity, and belong to the following families: a) PR-10 (Bet v 1-like) are present in a large number of plant foods. Birch pollen is generally the primary sensitizer; b) Profilin is a plant pan-allergen present in all eukaryotic cells. Primary sensitizers are in general grass or birch pollen.

\section{Animal-derived foods}

The main molecular classes involved in food allergy are shown in table II (p. 55). All but beta-lactoglobulin and alpha-lactalbumin are heat-resistant.

\section{Main molecules involved in hymenoptera venom allergy}

The main molecules involved in hymenoptera allergies are shown in table III (p. 56).

\section{Laboratory Methods used for CRD}

A technical analysis of the laboratory methods currently available to measure IgE to allergen components goes beyond the scope of this short guide. Essentially, two strategies are employed: a) Singleplex detects IgE specific for single molecular components. A direct knowledge of the patient by the specialist is required. It is a quantitative method; b) Multiplex detects IgE to a large, fixed panel of allergen molecules; the sensitization profile produced may be not necessarily completely associated with clinical symptoms. It is a semi-quantitative method that needs to be correctly interpreted by a specialist.

\section{Recommendations for a correct use of CRD in allergology}

The goal is to detect precisely patient's allergy profile in order (a) to prescribe the correct allergen immunotherapy (AIT) in those with respiratory allergy; and (b) to identify the risk of severe allergic reactions in patients with food allergy (9).

A diagnostic algorithm for poly-sensitized patients with respiratory allergy is depicted in figure $\mathbf{1}$ (p. 57). The main point is to detect $\operatorname{IgE}$ to markers of genuine sensitization to the single allergen sources (pollens, molds, mites, animal allergens, or natural rubber latex) and to cross-reactive molecules. Only genuine reactors will be considered for AIT. In view of the high homology between different cross-reacting allergens (e.g., polcalcins, profilins), detecting IgE to one single representative molecule is considered sufficient to diagnose or rule out sensitization $(10,11)$. A diagnostic algorithm for food-allergic patients is shown in figure 2 (p. 57). The clinical risk has to be assessed for every relevant allergen source on the basis of the heat- and pepsin-stability of the sensitizing protein(s).

A diagnostic algorithm for patients showing poly-sensitization to hymenoptera venoms is shown in figure 3 (p. 57). Again, the goal is to detect the presence of $\operatorname{IgE}$ specific for genuine markers of sensitization rather than cross-reactive molecules, in order to prescribe the appropriate venom immunotherapy.

\section{The interpretative comment by the Lab}

The experienced pathologist may play a role in the diagnosis of allergic diseases only if he/she receives clinical details along with the request of specific $\mathrm{IgE}$ measurement. 
Table I - Main molecules detected in the most important sources of respiratory allergy.

\begin{tabular}{|c|c|c|c|}
\hline Source & Major specific allergens & Minor specific allergens & Cross-reactive allergens \\
\hline grass (Phleum pratense) & $\begin{array}{l}\mathrm{Phl} \mathrm{p} 1^{1} \\
\mathrm{Phl} \mathrm{p} 5^{1}\end{array}$ & $\begin{array}{l}\text { Phl p } 2^{1} \\
\text { Phl p } 4^{1} \\
\text { Phl p } 6^{1} \\
\text { Phl p } 1^{1}\end{array}$ & $\begin{array}{l}\text { Phl p7 (polcalcin) }{ }^{1} \\
\text { Phl p } 12 \text { (profilin) }^{1}\end{array}$ \\
\hline grass (Cynodon dactylon) & Cyn d $1^{1}$ & & $\begin{array}{l}\text { Cyn d } 7 \text { (polcalcin) } \\
\text { Cyn d } 12 \text { (profilin) }\end{array}$ \\
\hline birch (Betula verucosa) & Bet $v 1^{1}$ & Bet $v 6^{1}$ & $\begin{array}{l}\text { Bet v } 2 \text { (profilin) })^{1} \\
\text { Bet v } 4 \text { (polcalcin) }{ }^{1}\end{array}$ \\
\hline Parietaria judaica & Par j 2 (nsLTP) ${ }^{1}$ & Par j 1 (nsLTP) & $\begin{array}{l}\text { Par j } 3 \text { (profilin) } \\
\text { Par j } 4 \text { (polcalcin) }\end{array}$ \\
\hline olive (Olea europea) & Ole e $1^{1}$ & $\begin{array}{l}\text { Ole e } 7(\text { nsLTP })^{1} \\
\text { Ole e } 9(1-3 \text { beta-glucanase })^{1} \\
\text { Ole } 5 \text {, Ole } 6 \text {, Ole } 10 \text {, Ole } 11\end{array}$ & $\begin{array}{l}\text { Ole e } 2 \text { (profilin) } \\
\text { Ole e } 3 \text { (polcalcin) } \\
\text { Ole e } 8 \text { (polcacin) }\end{array}$ \\
\hline cypress (Cupressus arizonica) & Cup a $1^{1}$ & & \\
\hline mugwort (Artemisia vulgaris) & Art v 1 (defensin-like protein $)^{1}$ & $\begin{array}{l}\text { Art v } 3(\mathrm{nsLTP})^{1} \\
\text { Art v } 6\end{array}$ & $\begin{array}{l}\text { Art v } 4 \text { (profilin) } \\
\text { Art v } 5 \text { (polcalcin) }\end{array}$ \\
\hline ragweed (Ambrosia artemisiifolia) & Amb a 1 (pectate-lyase $)^{1}$ & $\begin{array}{l}\text { Amb a } 3 \\
\text { Amb a } 4 \text { (defensin-like protein) } \\
\text { Amb a } 6 \text { (nsLTP) }\end{array}$ & $\begin{array}{l}\text { Amb a } 8 \text { (profilin) } \\
\text { Amb a } 9 \text { (polcalcin) }\end{array}$ \\
\hline plantain (Plantago lanceolata) & Pla $11^{1}$ & & Pla 12 (profilin) \\
\hline $\begin{array}{l}\text { plane } \\
\text { (Platanus acerifolia) }\end{array}$ & Pla a $1^{2}$ & $\begin{array}{l}\text { Pla a } 2^{2} \\
\text { Pla a } 3(\text { nsLTP })^{2}\end{array}$ & \\
\hline Dermatophagoides pt. & $\begin{array}{l}\text { Der p } 1{\text { (cistein-proteasi })^{1}} \\
\text { Der p } 2{\text { (NPC } 2)^{1}}^{\text {Der } \mathrm{p} 23^{1}}\end{array}$ & 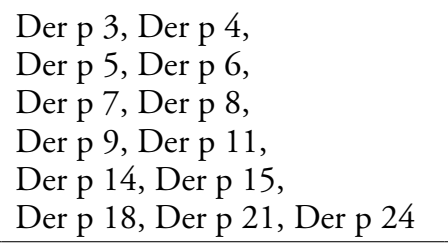 & $\begin{array}{l}\text { Der p } 10 \text { (tropomyosin) }{ }^{1} \\
\text { Der p } 20 \text { (arginine-kinase) }\end{array}$ \\
\hline cat (Felis domesticus) & Fel d $1^{1}$ (secretoglobulin) & $\begin{array}{l}\text { Fel d } 3 \text { (cistatin) } \\
\text { Fel d } 5 \text { (IgA) } \\
\text { Fel d } 6 \text { (IgG) } \\
\text { Fel d } 7 \\
\text { Fel d } 8\end{array}$ & $\begin{array}{l}\text { Fel d } 2 \text { (serum albumin })^{1} \\
\text { Fel d } 4 \text { (lipocalin })^{1}\end{array}$ \\
\hline $\operatorname{dog}$ (Canis familiaris) & Can f 1 (lipocalin) $)^{1}$ & Can f 5 (kallicrein $)^{1}$ & $\begin{array}{l}\text { Can f } 2 \text { (lipocalin) })^{1} \\
\text { Can f } 6 \text { (lipocalin) } \\
\text { Can f } 3 \text { (serum albumin })^{1}\end{array}$ \\
\hline Alternaria alternata & Alt a $1^{1}$ & $\begin{array}{l}\text { Alt a } 3 \text {, Alt a } 4 \text {, Alt a } 5 \text {, Alt a } 6^{2}, \\
\text { Alt a } 7 \text {, Alt a } 8 \text {, Alt a } 10 \text {, Alt a } \\
12 \text {, Alt a } 13 \text {, Alt a } 14 \text {, Alt a } 15\end{array}$ & \\
\hline latex & $\begin{array}{l}\text { Hev b } 1^{1}, \text { Hev b } 3^{1} \\
\text { Hev b } 5^{1}, \text { Hev b } 6^{1}\end{array}$ & $\begin{array}{l}\text { Hev b } 4, \text { Hev b } 7, \text { Hev b } 9^{1} \\
\text { Hev b } 11^{1}, \text { Hev b } 12, \\
\text { Hev b } 13, \text { Hev b } 14, \\
\text { Hev b } 15\end{array}$ & Hev b 8 (profilin) $)^{1}$ \\
\hline
\end{tabular}

${ }^{1}$ Available in singleplex diagnostics. ${ }^{2}$ Available only in multiplex diagnostics (ISAC). 
Table II - Main allergens detected in the most important food sources.

\begin{tabular}{|c|c|c|c|}
\hline Source & Major specific allergen & Minor specific allergen & Cross-reactive allergens \\
\hline peach & Pru p $3(\text { nsLTP) })^{1}$ & Pru p 7 (peamaclein) & $\begin{array}{l}\text { Pru p } 1 \text { (PR-10) })^{1} \\
\text { Pru p } 4 \text { (profilin) }\end{array}$ \\
\hline apple & Mal d $3(\text { nsLTP })^{1}$ & & $\begin{array}{l}\text { Mal d } 1 \text { (PR-10)1 } \\
\text { Mal d } 4 \text { (profilin) }\end{array}$ \\
\hline hazelnut & $\begin{array}{l}\text { Cor a } 14 \text { (2S-albumin })^{1} \\
\text { Cor a } 8 \text { (nsLTP })^{1} \\
\text { Cor a } 9 \text { (legumin })^{1}\end{array}$ & $\begin{array}{l}\text { Cor a } 6 \text {, Cor a 10, Cor a } 11 \text { (vicilin), Cor a } \\
12 \text { (oleosin), Cor a } 13 \text { (oleosin) }\end{array}$ & $\begin{array}{l}\text { Cor a } 1 \text { (PR-10)1 } \\
\text { Cor a } 2 \text { (profilin) }\end{array}$ \\
\hline walnut & $\begin{array}{l}\text { Jug r } 1 \text { (2S-albumin })^{1} \\
\text { Jug r } 2 \text { (vicilin) }^{2} \\
\text { Jug r } 3 \text { (nsLTP) }^{1}\end{array}$ & Jug r 4 (legumin) & \\
\hline brazilian nut & Ber e $1(2 S \text {-albumin })^{1}$ & Ber e 2 (cupin) & \\
\hline peanut & $\begin{array}{l}\text { Ara h } 1 \text { (vicilin) })^{1} \\
\text { Ara h } 2(\text { (2S-albumin })^{1} \\
\text { Ara h } 3 \text { (legumin }^{1} \\
\text { Ara h } 9{\text { (nsLTP })^{1}}^{1}\end{array}$ & $\begin{array}{l}\text { Ara h } 6 \text { (2S-albumin }^{1} \\
\text { Ara h } 7 \text { (2S-albumin) } \\
\text { Ara h } 10 \text { (oleosin) } \\
\text { Ara h } 11 \text { (olesosin) } \\
\text { Ara h } 12 \text {, Ara h 13, Ara h 14, Ara h 15, Ara } \\
\text { h 16, Ara h } 17\end{array}$ & $\begin{array}{l}\text { Ara h } 8 \text { (PR-10)1 } \\
\text { Ara h } 5 \text { (profilin) }\end{array}$ \\
\hline cashew (pistachio) & $\begin{array}{l}\text { Ana o } 1 \text { (vicili) } \\
\text { Ana o } 2{\text { (legumin })^{2}}^{1} \\
\text { Ana o } 3 \text { (2S-albumin })^{1}\end{array}$ & & \\
\hline soybean & 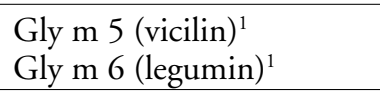 & Gly m 7, Gly m 8 (2S-albumin) & $\begin{array}{l}\text { Gly m } 4 \text { (PR-10) }{ }^{1} \\
\text { Gy m } 3 \text { (profilin) }\end{array}$ \\
\hline sesame & $\begin{array}{l}\text { Ses i } 1 \text { (2S-albumin) } \\
\text { Ses i } 3 \text { (vicilin) } \\
\text { Ses i } 4 \text { (oleosin) } \\
\text { Ses i } 5 \text { (oleosin) } \\
\text { Se i } 6 \text { (legumin) }\end{array}$ & $\begin{array}{l}\text { Ses i } 2 \text { (2S-albumin) } \\
\text { Ses i } 7 \text { (legumin) }\end{array}$ & \\
\hline wheat & $\begin{array}{l}\text { Tri a } 14(\text { nsLTP })^{1} \\
\text { Tri a } 19(\omega-5 \text { gliadin })^{1}\end{array}$ & $\begin{array}{l}\text { Tri a } 18 \text { (aglut / isolect) } \\
\text { Tri a } 20 \text { ( } \gamma \text {-gliadin) } \\
\text { Tri a } 25 \text { (tioredoxin) } \\
\text { Tri a } 26 \text { e } 36 \text { (glutenins) } \\
\text { Tri a } 37 \text { ( } \alpha \text {-purotionin) } \\
\text { Tri a } 30 \text { ( } \alpha \text {-amilase inhib) }{ }^{2} \\
\text { Tri a } 41,42,43,44,45\end{array}$ & Tri a 12 (profilin) \\
\hline cow's milk & $\begin{array}{l}\text { Bos d } 4(\alpha \text {-lactalbumin })^{1} \\
\text { Bos d } 5(\beta \text {-lactoglobulin })^{1} \\
\text { Bos d } 8 \text { (casein })^{1}\end{array}$ & $\begin{array}{l}\text { Bos d } 2 \text { (lipocalin) } \\
\text { Bos d } 3 \text { (S100 CBP) } \\
\text { Bos d } 6 \text { (serum albumin) }{ }^{1} \\
\text { Bos d } 7 \text { (Immunoglobulin) } \\
\text { Bos d Lactoferrin }{ }^{2}\end{array}$ & \\
\hline hen's egg & $\begin{array}{l}\text { Gal d } 1 \text { (ovomucoid) })^{1} \\
\text { Gal d } 2 \text { (ovoalbumin) }{ }^{1} \\
\text { Gal d } 3 \text { (ovotranferrin) }{ }^{1}\end{array}$ & 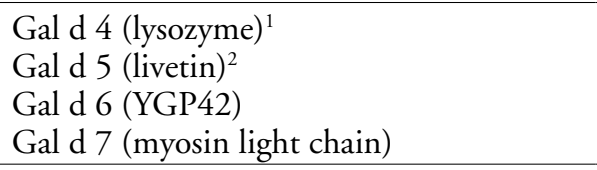 & \\
\hline cod fish & 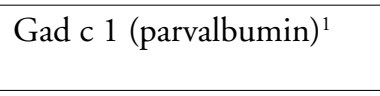 & $\begin{array}{l}\text { Gad m } 2 \text { (enolase) } \\
\text { Gad m } 4 \text { (aldolase) }\end{array}$ & \\
\hline shrimp & $\begin{array}{l}\text { Pen i } 1 \text { (tropomyosin) })^{1} \\
\text { Pen m } 1 \text { (tropomyosin) })^{2}\end{array}$ & $\begin{array}{l}\text { Pen m } 2{\text { (arginine-kinase })^{2}} \\
\text { Pen m } 3 \text { (Myosin light chain) } \\
\text { Pen m } 4 \text { (sarcoplasmic CBP) }{ }^{2}\end{array}$ & \\
\hline
\end{tabular}

${ }^{1}$ Currently available for singleplex diagnostics. ${ }^{2}$ Available only in multiplex (ISAC) diagnostics. 
Table III - main allergenic molecules detected in hymenoptera venoms.

\begin{tabular}{|c|c|c|}
\hline Source & Allergen & Biochemical name \\
\hline apis mellifera (honey bee) & $\begin{array}{l}\text { Api m } 1^{1} \\
\text { Api m } 2^{1} \\
\text { Api m } 3^{1} \\
\text { Api m } 4^{2} \\
\text { Api m } 5^{1} \\
\text { Api m } 6 \\
\text { Api m } 7 \\
\text { Api m } 8 \\
\text { Api m } 9 \\
\text { Api m } 10^{1} \\
\text { Api m } 11 \\
\text { Api m } 12\end{array}$ & $\begin{array}{l}\text { phospholipase } \mathrm{A}_{2} \\
\text { ialuronidase } \\
\text { acid phosphatase } \\
\text { mellitin } \\
\text { dipeptidyl-peptidase IV } \\
\text { cub serin-protease } \\
\text { carboxilesterase } \\
\text { serin-carboxipeptidase } \\
\text { icarapin variant } 2 \\
\text { vitellogenin }\end{array}$ \\
\hline vespula vulgaris (yellow jacket) & $\begin{array}{l}\text { Ves } \vee 1^{1} \\
\text { Ves } \vee 2 \\
\text { Ves } \vee 3 \\
\text { Ves }>5^{1} \\
\text { Ves } \vee 6\end{array}$ & $\begin{array}{l}\text { phospholipase } A_{1} \\
\text { ialuronidase } \\
\text { dipeptidyl-peptidase IV } \\
\text { antigen } 5 \\
\text { vitellogenin }\end{array}$ \\
\hline polistes dominulus (paper wasp) & $\begin{array}{l}\text { Pold } 1 \\
\text { Pol d } 4 \\
\text { Pol d } 5^{1}\end{array}$ & $\begin{array}{l}\text { phospholipase } A_{1} \\
\text { serin-protease } \\
\text { antigen } 5\end{array}$ \\
\hline $\begin{array}{l}\text { vespa crabro } \\
\text { (hornet) }\end{array}$ & $\begin{array}{l}\text { Vesp c } 1 \\
\text { Vesp c } 5\end{array}$ & $\begin{array}{l}\text { phospholipase } A_{1 b} \\
\text { antigen } 5\end{array}$ \\
\hline
\end{tabular}

${ }^{1}$ Available for singleplex diagnostics. ${ }^{2}$ Available only for multiplex (ISAC) diagnostics.

A series of examples in respiratory or latex allergy are shown in table IV (p. 58), while some examples for food allergy are shown in table $\mathbf{V}$ (p. 59).

In hymenoptera venom allergy, molecular findings should be interpreted in the light of clinical history and of in-vivo and in-vitro results with whole venom extracts. Molecular allergens may confirm sensitization to CCDs. A differential diagnosis between paper wasp and yellow jacket allergy can be afforded if the difference in IgE levels between Ves v 5 e Pol d 5 exceeds 45-50\%. Allergen ISAC microarray provides a semi-quantitative measurement of $\operatorname{IgE}$ to 112 allergen molecules. It has to be considered a $3^{\text {rd }}$ level analysis, to be used by the specialist to solve doubts and complex cases; the interpretation of the results should be left to the experienced allergologist with special expertise in molecular allergology and is not a duty of the pathologist.

\section{Conflict of interest}

The authors declare that they have no conflict of interest.

\section{References}

1. Iancovici-Kidon M, Tim CF. Component-specific immunoglobulin $\mathrm{E}$ in the diagnosis of allergic disease in childhood: more of the same or something more? Isr Med Assoc J 2007; 9:476-8.
2. Hauser M, Roulias A, Ferreira F, Egger M. Panallergens and their impact on the allergic patient. Allergy, Asthma and Clinical Immunology 2010; 6:1.

3. Valenta R, Twaroch T, Swoboda I. Component-resolved diagnosis to optimize allergen-specific immunotherapy in the Mediterranean area. J Invest Allergol Clin Immunol 2007; 17(Suppl 1):88-92.

4. Sastre J. Molecular diagnosis and immunotherapy. Curr Opin Allergy Clin Immunol 2013; 13:646-50.

5. Schmidt Andersen M-B, Hall S, Dragsted LO. Identification of European allergy patterns to the allergen families PR-10, LTP and profilin from Rosaceae fruits. Clinic Rev Allergy Immunol 2011; 41:4-19.

6. Peixinho C, Tavares-Rataldo P, Tomàs MR, Taborda-Barata L, Tomaz CT. Latex allergy: new insights to explain different sensitization profiles in different risk groups. Br J Dermatol 2008; 159:132-6.

7. Muller UR, Johansen N, Petersen AB, Fromberg-Nielsen J, Haeberli G. Hymenoptera venom allergy: analysis of double positivity to honey bee and Vespula venom by estimation of $\operatorname{IgE}$ antibodies to species-specific major allergens Api m 1 and Ves v 5. Allergy 2009; 64:543-8.

8. Radauer C, Bublin M, Wagner S, Mari A, Breiteneder H. Allergens are distributed into few protein families and possess a restricted number of biochemical functions. J Allergy Clin Immunol 2008; 121:847-52.

9. Canonica GW, Ansotegui IJ, Pawankar R, Schmid-Grendelmeier P, van Hage M, Baena-Cagnani CE, et al. A WAO-ARIA-GA${ }^{2} \mathrm{LEN}$ consensus document on molecular based allergy diagnostics. World Allergy Organ J 2013; 6:17. 
Figure 1 - General diagnostic algorithm in case of multiple sensitization to respiratory allergens on in-vivo or in-vitro tests with whole allergen extracts. Genuine markers of sensitization and of cross-reactivity have to be chosen on the basis of the positive findings with extracts.

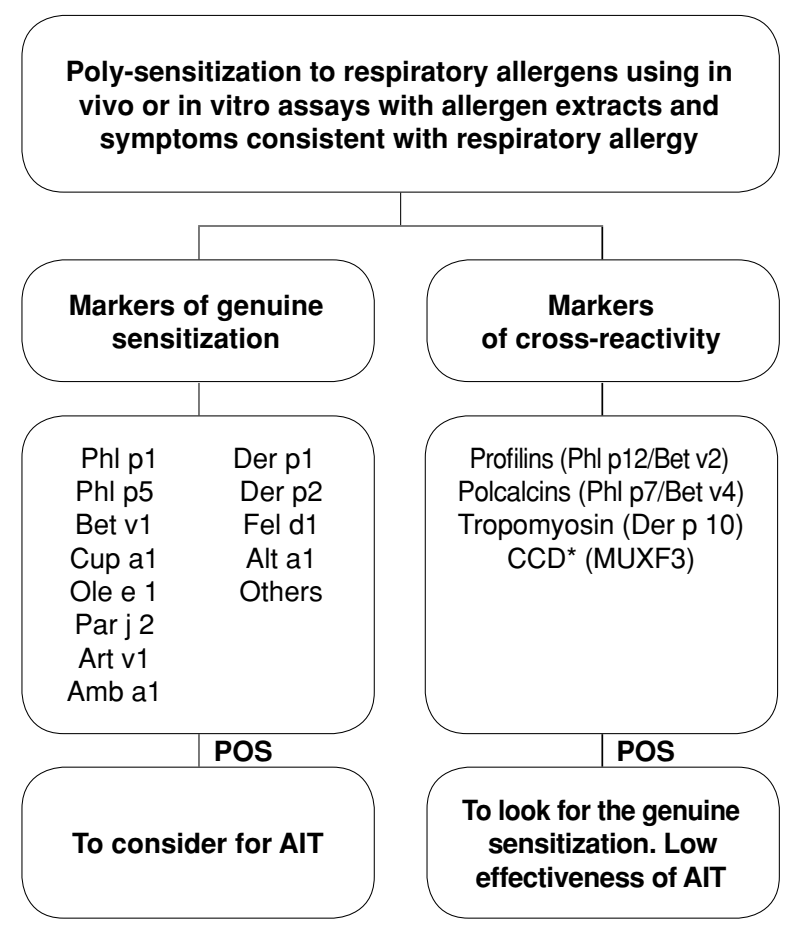

*The detection of IgE to CCD will be performed only in case of multiple positivity in-vitro.

Figure 3 - CRD algorithm in case of positive for both honey bee and vespids using whole allergen extracts.

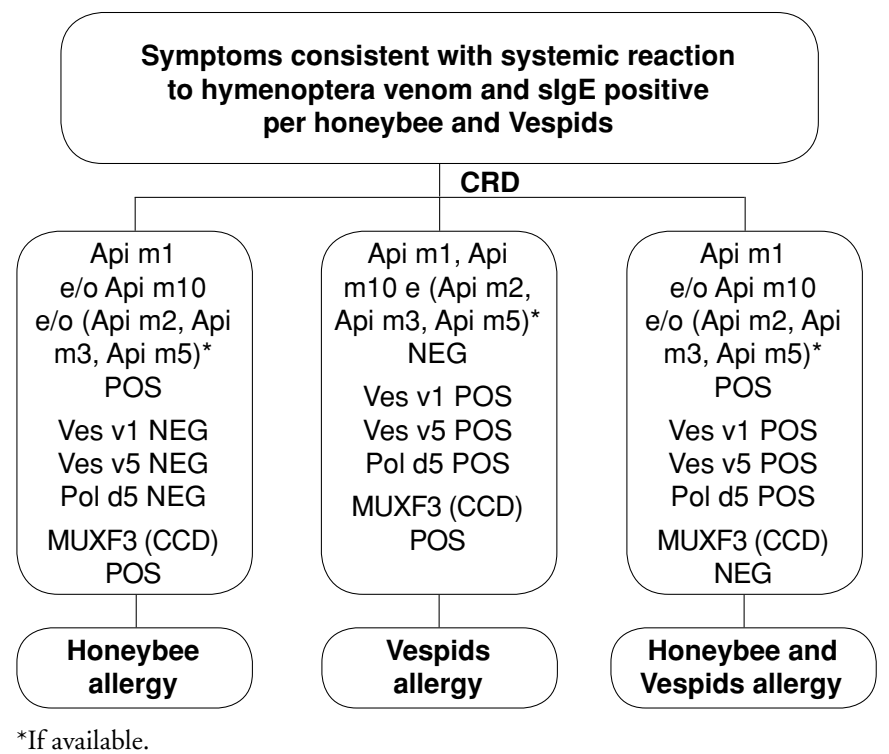

Figure 2 - General diagnostic algorithm in case of multiple sensitization to food allergens on in-vivo or in-vitro tests with whole allergen extracts. Genuine markers of sensitization and of cross-reactivity have to be chosen on the basis of the positive findings with extracts.

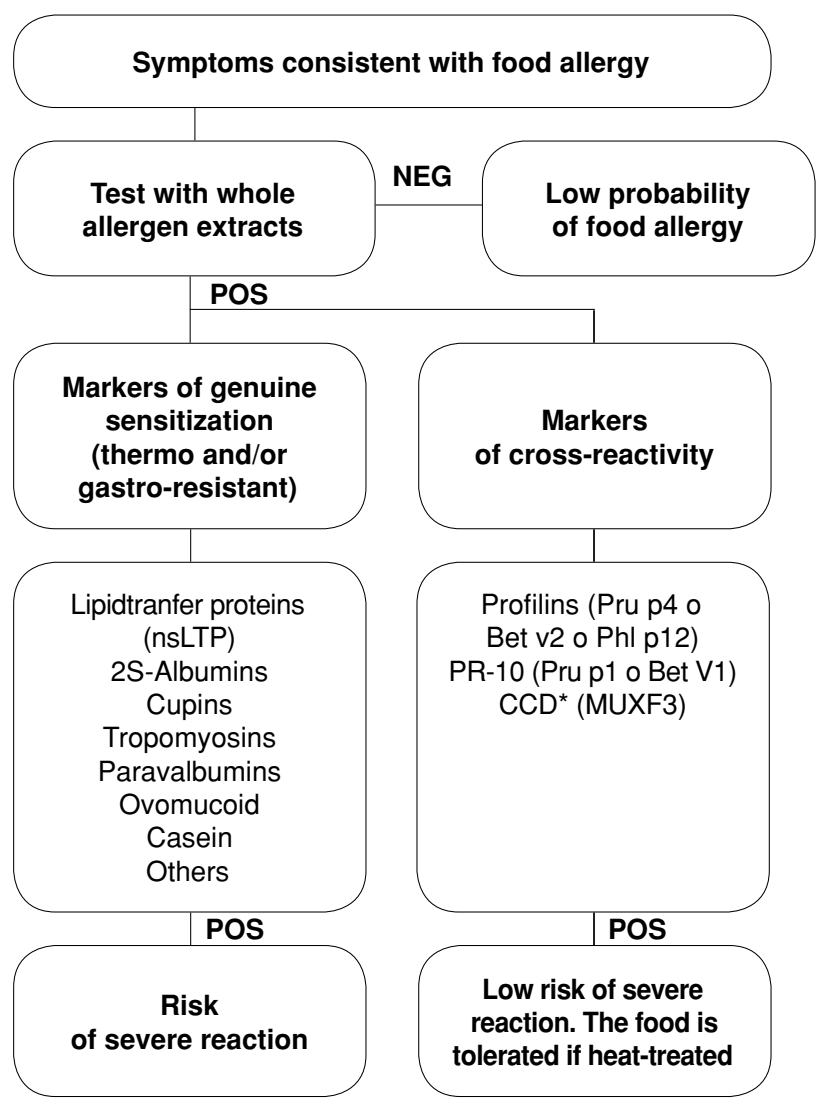

*the detection of IgE to CCD will be performed only in case of multiple positivity in-vitro.

10. Valenta R, Hayek B, Seiberler S, Bugajska-Schretter A, Niederberger $\mathrm{V}$, Twardors A, et al. Calcium-binding allergens: from plants to man. Int arch Allergy Immunol 1998; 117:160-6.

11. Villalta D, Asero R. Sensitization to pollen pan-allergen profiling: is the detection of Immunoglobulin E to multiple homologous proteins from different sources clinically useful? J Investig Allergol Clin Immunol 2010; 20:591-5. 
Table IV - Some interpretative comments to molecular diagnostics in respiratory and latex allergy.

\begin{tabular}{|c|c|}
\hline Case & Interpretative comment \\
\hline \multicolumn{2}{|l|}{ Cross-reacting molecules } \\
\hline $\mathrm{IgE}$ reactivity to $\mathrm{PR}-10$ & $\begin{array}{l}\text { primary sensitization to birch pollen with cross-reactivity to fruits / vegetable, pos- } \\
\text { sibly causing OAS }\end{array}$ \\
\hline IgE reactivity to Profilin (Phl p 12/Bet v 2) & $\begin{array}{l}\text { profilins are plant panallergens, are frequently cross-reacting and may cause OAS to } \\
\text { different plant-derived foods }\end{array}$ \\
\hline IgE reactivity to polcalcins $(\mathrm{Phl} \mathrm{p} 7 /$ bet $\mathrm{v} 4)$ & $\begin{array}{l}\text { polcalcins are pollen panallergens and may be responsible for cross-reactivity be- } \\
\text { tween botanically unrelated pollens }\end{array}$ \\
\hline CCD & $\begin{array}{l}\text { IgE to CCD are cross-reactive and directed against ubiquitous epitopes of plants, in- } \\
\text { vertebrates, latex, and hymenoptera venom. This positivity has no clinical relevance }\end{array}$ \\
\hline \multicolumn{2}{|l|}{ Seasonal allergens } \\
\hline $\begin{array}{l}\text { single or multiple IgE reactivity to genuine } \\
\text { pollen allergens with / without cross-react- } \\
\text { ing allergens }\end{array}$ & $\begin{array}{l}\text { the patient shows genuine hypersensitivity to the following pollen sources: ... as } \\
\text { shown by IgE reactivity to ... }\end{array}$ \\
\hline \multicolumn{2}{|l|}{ Perennial allergens } \\
\hline $\begin{array}{l}\text { perennial symptoms and positive in vivo / } \\
\text { in vitro test with mite extract }\end{array}$ & $\begin{array}{l}\text { Der p 1-2 positive: the test confirms mite allergy; Der p } 1-2 \text { negative: mite sensitiza- } \\
\text { tion not confirmed by the test, but the patient might be sensitized to mite allergens } \\
\text { that are currently unavailable for molecular diagnostics }\end{array}$ \\
\hline animal allergens & $\begin{array}{l}\text { Fel d } 1 \text { or Can } \mathrm{f} 5 \text { positive: primary sensitization to cat / dog; } \\
\text { Can f } 5 \text { +/Can } \mathrm{f} 1 \text {-: the patient should be able to tolerate contact with female dogs; } \\
\text { Can } \mathrm{f} 1 \text { or other lipocalins positive: in view of possible cross-reactivity, the patient } \\
\text { might have symptoms in the presence of different species of animals; } \\
\text { Fel d 2-positive: the patient might develop allergic symptoms following the inges- } \\
\text { tion of pork meat due to cross-reactivity between serum albumins. Serum albumins } \\
\text { are partially heat-labile }\end{array}$ \\
\hline Aspergillus hypersensitivity & $\begin{array}{l}\text { Hypersensitivity to Asp f } 1 \text { and/or Asp f } 3 \text { is frequent in patients with respiratory } \\
\text { symptoms. Hypersensitivity to Asp f } 2 \text {, Asp f } 4 \text {, and/or Asp f } 6 \text { is more frequent in } \\
\text { broncho-pulmonary aspergillosis }\end{array}$ \\
\hline latex & $\begin{array}{l}\text { Patient monosensitized to Hev b } 8 \text { (profilin): this reactivity is clinically irrelevant. No } \\
\text { latex-safe procedures needed; } \\
\text { Patient sensitized to any other NRL allergen: primary sensitization to natural rubber latex; } \\
\text { Sensitization to Hev b 5, Hev b } 6 \text { or Hev b 11: possible cross-reactivity to plant foods }\end{array}$ \\
\hline
\end{tabular}


Table $\boldsymbol{V}$-Some interpretative comments to molecular diagnostics in food allergy.

\begin{tabular}{ll}
\hline Case & Comment \\
\hline fresh fruits allergy & $\begin{array}{l}\text { Sensitization to PR-10 or profilin: allergy caused by pollen / food cross-reactivity, } \\
\text { generally associated with local symptoms (OAS). Cooking abolishes allergenicity; } \\
\text { Sensitization to nsLTP with history of systemic symptoms: sensitization to heat- and } \\
\text { pepsin resistant allergen that may cause severe systemic reactions }\end{array}$ \\
\hline Huts and peanut allergy & $\begin{array}{l}\text { Hypersensitivity to seed storage proteins or nsLTPs: patient is sensitized to extremely } \\
\text { stable allergens that may cause systemic allergic reactions }\end{array}$ \\
\hline wheat allergy & $\begin{array}{l}\text { Hypersensitivity to Tri a 19 ( } \omega-5 \text { gliadin): patient sensitive to an allergy frequently } \\
\text { associated with food-dependent, exercise-induced anaphylaxis }\end{array}$ \\
\hline fish allergy & $\begin{array}{l}\text { Hypersensitivity to parvalbumin (Gad c 1 or Cyp c 1): in view of the high homology } \\
\text { between fish parvalbumins the patient is likely to react to most vertebrate fishes }\end{array}$ \\
\hline shrimp / invertebrates allergy & $\begin{array}{l}\text { Hypersensitivity to Pen a 1: confirmed allergy to shrimp and other invertebrates; } \\
\text { Hypersensitivity to shrimp extract but not to Pen a 1: possible sensitization to shrimp } \\
\text { allergens currently not available in the diagnostic kit }\end{array}$ \\
\hline Hypersensitivity to Bos d 8: patient sensitized to a heat-stable allergen causing symp- \\
toms after boiling; \\
Hypersensitivity to Bos d 4 and/or Bos d 5: patient sensitized to heat-labile allergens; \\
tolerance to cooked food possible \\
$\begin{array}{l}\text { Hypersensitivity to Gal d 1: patient sensitized to a heat- and pepsin- stable allergen. } \\
\text { Cooked foods may cause symptoms; } \\
\text { Hypersensitivity to gal d 2: patient sensitized to a heat-labile allergen. Tolerance to } \\
\text { cooked food possible }\end{array}$ \\
$\begin{array}{l}\text { Hypersensitivity to pork meat and to Fel d 2: hypersensitivity to cross-reacting se- } \\
\text { rum albumins (cat-pork syndrome); } \\
\text { Alpha-Gal sensitization: this sensitization may cause delayed (4-6 hours) food allergy } \\
\text { to red meat; } \\
\text { Poultry allergy and Gal d } 5 \text { sensitivity (available only on ISAC platform): poultry } \\
\text { meat / egg cross reactivity due to sensitization to alpha-livetin }\end{array}$ \\
\hline hen's egg allergy & \\
\hline allergy to meat &
\end{tabular}

